\title{
Effect of polyherbal mixture supplementation on incidence of mastitis and milk production in postpartum Murrah buffaloes
}

\author{
K Puhle Japheth, A Kumaresan, Bilal Ahmad Ganaie, PS Oberoi, SS Lathwal and Pawan Singh
}

Received: 30 May 2018 / Accepted: 24 November 2018 / Published online: 21 February 2019

(C) Indian Dairy Association (India) 2019

\begin{abstract}
The study was conducted at ICAR-NDRI to investigate the effect of polyherbal mixture supplementation on incidence of mastitis and milk production in postpartum Murrah buffaloes. A total of 60 buffaloes were utilized for the study and were randomly classified into two groups viz. control and treatment group (each 30 buffaloes). Buffaloes in the control group were fed with the routine ration as per the feeding schedule of NDRI (NRC, 2001+ 10\% extra energy). Buffaloes in the treatment group were supplemented with polyherbal mixture containing $25 \mathrm{~g}$ each of Ajwain, Haldi, Jeera, Methi, Saunf, Sowa and Sundh along with $25 \mathrm{~g}$ of kala namak and $250 \mathrm{~g}$ jaggery from the day of calving till day 10 of postpartum. The polyherbal mixture was grounded into fine powder, mixed in the concentrate and fed once a day. Milk samples were collected on day 7, 14, 21 and 28 postpartum and examined for somatic cells load by California Mastitis Test (CMT). The lactation total milk yield of both supplemented and non supplemented groups are also recorded. Proportion of Murrah buffaloes that were suspicious for mastitis were 20\% (day 7), 10\% (day 14), 3.3\% (day 21) and $0 \%$ (day 28) in supplemented group while it was $36.6 \%$ (day 7 ), $26.6 \%$ (day 14 ), $10 \%$ (day 21 ) and 6.6\% (day 28) in control group; there was significant difference $(\mathrm{P}<0.05)$ between control and supplemented group on day 7,21 and 28. The average total milk
\end{abstract}

\footnotetext{
K Puhle Japheth $(\bowtie)$

Department of Livestock Production Management,

International Institute of Veterinary Education Research, Bahu

Akbarpur, Rohtak-124001, Haryana, India

E-mail:puhleveto7@gmail.com Mobile:+919729163053

A Kumaresan

ICAR-National Dairy Research Institute, Southern Regional Station, Adugodi, Bengaluru, 560030, Karnataka, India
}

Bilal Ahmad Ganaie, PS Oberoi, SS Lathwal and Pawan Singh ICAR-National Dairy Research Institute, Karnal-132001, Haryana, India yield in supplemented group was $2642.87 \pm 75.45 \mathrm{~kg}$, while it was $2292.27 \pm 77.65 \mathrm{~kg}$ in non supplemented group. The total milk yield was significantly $(\mathrm{P}<0.05)$ higher in the supplemented group as compared to control group. It is inferred that supplementation of polyherbal mixture in postpartum Murrah buffaloes minimized the incidence of buffaloes suspicious for mastitis and increased the milk production.

Keywords: California Mastitis Test, Mastitis, Murrah buffaloes, Polyherbal mixture, Total milk yield

\section{Introduction}

Indian ranks first in milk production in the world by producing 163.9 million tonnes during 2016-2017 (DAHD\&F, 2017). Buffaloes contribute to more than $50 \%$ share of the total milk production in country as compared to cows (BAHS, 2016). However, mastitis is considered as one of the major health obstacle which reducing yield and quality of milk, thereby significantly affects the livelihood of the rural farmers (Sharma et al., 2012; NAAS, 2013). Bovine mastitis is globally recognized as the most common and costly disease affecting dairy herds. The disease causes huge financial losses to dairy industries through reduced yield, deaths and culling of affected cows and also by associated treatment costs. In India, the losses due to mastitis was first reported Rs. 52.9 crore annually in the year 1962 which took a gigantic leap to Rs. 6053.21 crore annually in the year 2001 (Sudhan and Sharma, 2010; Sharma et al., 2012). Mastitis management thus assumes high significance not only to curtail the losses associated with low production but most significantly to the human health related issues. Earlier, the effect of mastitis was considered to be restricted to udder only except in severe cases where systemic illness was observed. However, off late, increasing evidence indicate that mastitis is also a critical factor affecting the reproductive success of the herd (Srivastava et al., 2014; Kumar et al., 2016).

Antimicrobial resistance has become a common problem, especially in the areas of bacterial chemotherapy (Nandivada and Amyes, 1990). Moreover, animal treated with antibiotics for mastitis produce residues in the raw milk that escort toxicological effects to the consumers (Moretain et al., 1986). Herbs and their 
derivatives are believed to be safer than the allopathic veterinary remedies (Hashemi and Davoodi 2011). Therefore nowadays the use herbals is gaining its popularity among the people of both urban and rural areas due to several reasons such as cheap and easily availability, safe to use, effective and environmental friendly. Herbs are used either as such or in the form of extracts, tinctures, capsules and tablets to address a wide variety of medical conditions. In the present study, a combination of herbs was supplemented to investigate their effect on mastitis and milk production in postpartum Murrah buffaloes.

\section{Materials and methods}

\section{Selection of experimental animals}

The study was conducted at Livestock Research Centre (ICARNDRI, Karnal). The buffaloes were maintained under loose housing system. The buffaloes were provided both roughages and concentrate with ad libtum feeding of good quality green fodder throughout the year. Pregnant buffaloes were transferred to the calving pen two weeks prior to the expected date of calving. Buffaloes were milked twice a day (i.e. morning and evening). Murrah buffaloes which are healthy, free from physiological and anatomical disorders and also free from infections are taken for the study. A total of sixty (60) buffaloes that had calved normally (normal gestation period, delivery of calf without any extraneous assistance and expulsion of fetal membranes within $8 \mathrm{~h}$ after calving) were selected for the experiment. The experimental animals were randomly categorized into two groups as control group and treatment group, each group consisting of 30 animals.

\section{Preparation and supplementation of polyherbal mixture in buffaloes}

Each individual herb was procured from the local market after assessing their quality. The polyherbal mixtures used in the study were Ajwain (Trachyspermum ammi), Haldi (Curcuma longa), Jeera (Cuminum cyminum Linn), Methi (Trigonella foenumgraecum), Saunf (Foeniculum vulgare), Sowa (Anethum graveolens), Sundh (Zingiber officinale), Kala namak and Gur. Before feeding, each herb was ground thoroughly. Animals in the control group are fed as per standard feeding schedule of NDRI farm ( $+10 \%$ of energy NRC, 2001), while animals in treatment group were supplemented with polyherbal mixture in addition to the standard feeding. A total of $175 \mathrm{~g}$ of herbal mixture $(25 \mathrm{~g}$ each herb) was supplemented along with $25 \mathrm{~g}$ Kala namak and $250 \mathrm{~g}$ of Jaggery to each buffalo. All the ingredients were mixed in the concentrate and fed once a day (morning) from the day of calving till day 10 post-partum.

\section{Collection of milk sample for California Mastitis test (CMT)}

Milk samples were collected on day 7, 14, 21 and 28 of postpartum and examined for somatic cells load by California Mastitis Test (CMT). About 4-5 ml of milk was collected in a strip cup after discarding the first 2-3 streaks of milk from the teat. An equal amount of CMT testing reagent was added to the cup and mixed properly by gentle circular movements of the paddle for about 10 sec. Reaction occurred immediately which was accompanied by precipitation and gel formation in the positive cases due to presence of leukocytes. Depending upon the degree of gel formation, the interpretation was done as given by Klastrup and Schmidt Madsen (1974). The lactation total milk yield of both supplemented and non supplemented groups were also recorded. The data were subjected to chi-square test to see the significant difference between the groups.

\section{Results and discussion}

The proportion of animals negative, traces and suspicious for mastitis, as detected by California Mastitis Test in control and polyherbal mixture supplemented Murrah buffaloes were presented in table 1 and figure 1. Proportion of Murrah buffaloes with suspicious for mastitis on day 7, 14, 21 and 28 were $20 \%$, $10 \%, 3.3 \%$ and $0 \%$ in supplemented group, while it was $36.6 \%$, $26.6 \%, 10 \%$ and $6.6 \%$ in control group. There was significant difference $(\mathrm{P}<0.05)$ between control and supplemented groups on day 7, 21 and 28. The number of buffaloes suspicious for mastitis was significantly $(\mathrm{P}<0.05)$ lower in supplemented group. Similar findings were also reported by Sharma et al. (2013) that better udder health of cows in herb supplemented animals could be attributed to their better immune status due to active principles in herbs. Sunder et al. (2013) also reported similar improvement in udder health of mastitis affected cows with feeding of Morinda citrifolia fruit juice. Similarly, feeding Isatidis Radix has also been demonstrated to suppress the growth of E. coli and $H$. pylori and increases blood neutrophil phagocytosis (Chan et al., 2008). Bhawana et al. (2011) also reported that antibacterial mechanism of nanocurcumin was due to its adhering to the bacterial cell wall, causing complete breakage then penetrating inside the cell, disrupting the structure of cell and finally leading to cell death.

It was also reported that phyllemblin, a benzoid compound, have a profound antibacterial activity against Streptococcus pyogenes, Staphylococcus aureus and Klebsiella pneumoniae (Javale and Sabnis 2010). Also, flavanoids and other anti-oxidants help to reduce udder inflammation (Sharma et al., 2010). Khana et al. (2018) reported that herbal Amla extract was the most economical one for the treatment of subclinical mastitis in dairy buffaloes.

The lactation total milk in control group was $2292.27 \pm 77.65 \mathrm{~kg}$, while it was $2642.87 \pm 75.45 \mathrm{~kg}$ in supplemented group (Table 2). The total milk yield was significantly $(\mathrm{P}<0.05)$ higher in the polyherbal mixture supplemented group. There was also significant increase in the total milk yield in the supplemented group. Similarly, Singhal (1995) reported that herbal supplementation showed galactopoietics activity and can be 
Figure 1 Percentage of animals suspicious for mastitis as detected by California Mastitis Test in control and polyherbal mixture supplemented Murrah buffaloes

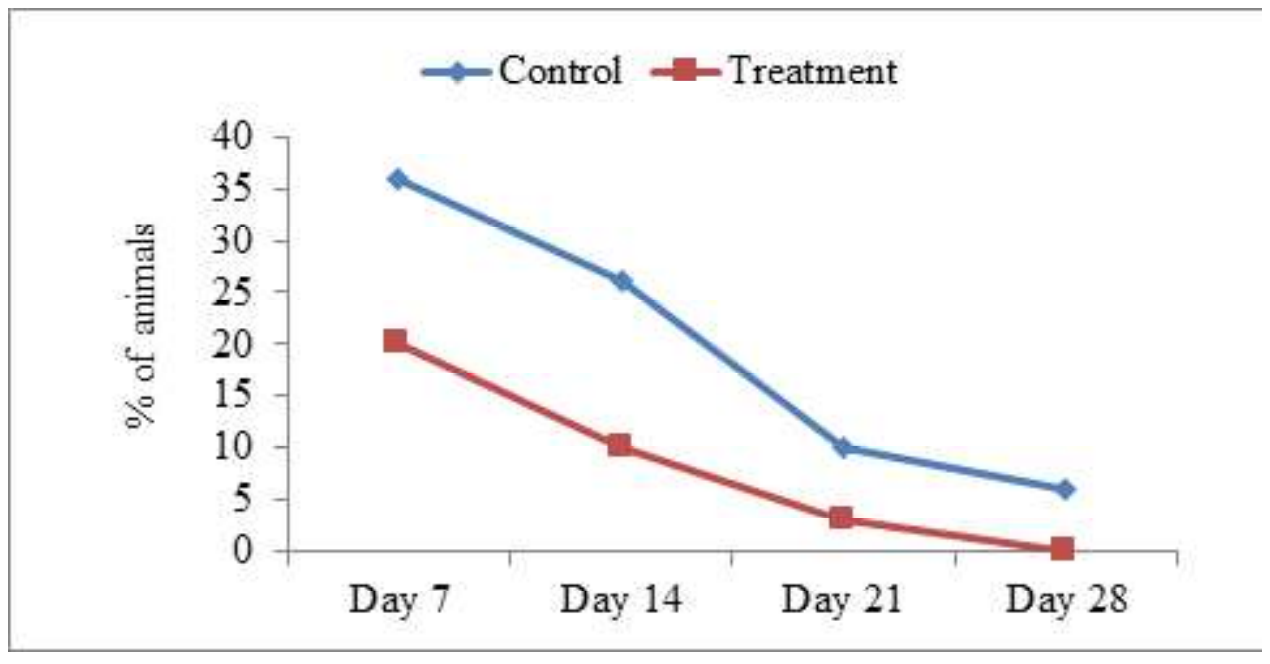

Table 1 Percentage of animals negative, traces and suspicious for mastitis as detected by California Mastitis Test in control and polyherbal mixture supplemented Murrah buffaloes

\begin{tabular}{|c|c|c|c|c|c|c|c|c|c|}
\hline \multirow[t]{2}{*}{ Groups } & \multirow[t]{2}{*}{ Remarks } & \multicolumn{2}{|c|}{ Day 7} & \multicolumn{2}{|c|}{ Day 14} & \multicolumn{2}{|c|}{ Day 21} & Day 28 & \multirow[b]{2}{*}{$\%$} \\
\hline & & No. & $\%$ & No. & $\%$ & No. & $\%$ & No. & \\
\hline \multirow[t]{4}{*}{ Control $(n=30)$} & $0(\mathrm{~N})$ & 2 & 6.6 & 2 & 6.6 & 3 & 10 & 9 & 30 \\
\hline & $*(\mathrm{~T})$ & 17 & 56 & 20 & 66.6 & 24 & 80 & 19 & 63.3 \\
\hline & $* *(1)$ & $11^{\mathrm{a}}$ & 36.6 & 8 & 26.6 & $3^{\mathrm{a}}$ & 10 & $2^{\mathrm{a}}$ & 6.6 \\
\hline & Total & 30 & 100 & 30 & 100 & 30 & 100 & 30 & 100 \\
\hline \multicolumn{2}{|c|}{ Treatment $(n=30) 0 \quad(N)$} & 6 & 20 & 13 & 43.3 & 11 & 36.6 & 14 & 46.6 \\
\hline & Total & 30 & 100 & 30 & 100 & 30 & 100 & 30 & 100 \\
\hline
\end{tabular}

Means with different superscripts in a row differ significantly $(\mathrm{P}<0.05)$

( $\mathrm{N}=$ Negative, $\mathrm{T}=$ Traces, $1=$ Suspicious)

Table 2 Average total milk yield in control and supplemented Murrah buffaloes

\begin{tabular}{lc}
\hline Animals groups & Total milk yield $(\mathrm{kg})$ \\
\hline Control $(\mathrm{n}=30)$ & $2292.27^{\mathrm{a}} \pm 77.65$ \\
Treatment $(\mathrm{n}=30)$ & $2642.87^{\mathrm{b}} \pm 75.45$ \\
\hline
\end{tabular}

Mean with different superscript within the row differs significantly $(\mathrm{P}<0.05)$

considered as an alternative for lactogenic hormones for inducing and enhancing milk yield in crossbred cows. Fleiss (1988) also reported Fenugreek seed are widely used as a galactagogue for nursing mothers to increase breast milk supply. Thakur et al. (2006) also reported that dietary supplementation of commercial herbal feed additive (Zingiber officinale, Adds racemosus, Lepidium sativum, Fragonella facunm, Ptychotis ajowan, Accacium sativam, Anacycus pyrethrum, Anaqua sodichlorium, Ficus religosa and Myrictica officials) to lactating crossbred cow, increased the milk yield. Supplementation of Shatavari, Jivanti and Fenugreek in equal proportion at the dose rate of 60 $\mathrm{g} / \mathrm{cow} /$ day resulted in significant increase in milk yield and daily return income in lactating Kankrej cows (Patel et al., 2017).

Likewise, in our study, the antioxidant, anti-inflammatory, antimicrobial and galactogouge properties of herbs such as Ajwain (Trachyspermum ammi), Haldi (Curcuma longa), Jeera (Cuminum cyminum Linn), Methi (Trigonella foenum-graecum), Saunf (Foeniculum vulgare), Sowa (Anethum graveolens) and Sundh (Zingiber officinale) might have been contributed in the improvement of udder health thereby minimizing the incidence 
Figure 2 Average total milk yield in control and supplemented Murrah buffaloes

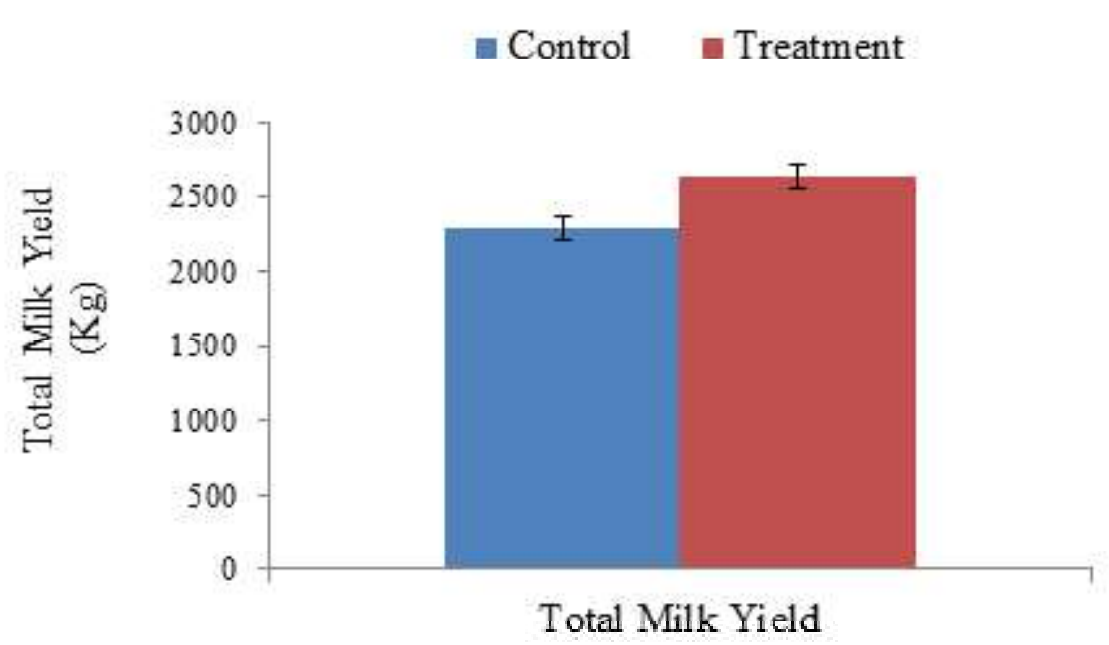

of buffaloes suspicious for mastitis and enhancing the milk production.

\section{Conclusions}

Polyherbal mixture supplementation was found to be effective in reducing the proportion of Murrah buffaloes suspicious for mastitis and enhancing milk production. Therefore, it can be suggested that, this herbal mixture could be use as a preventive strategy to treat the mastitis and as a means of galactagouge in buffaloes.

\section{Acknowledgements}

The authors wish to thank to the Director of ICAR-NDRI Karnal, for providing the necessary facilities to carry out the research. Also extend our gratitude to NFBSFARA project and UGC- RGNF for their financial assistant.

\section{References}

BAHS (2016) Basic Animal Husbandry and Fisheries Statistics. Government of India Ministry of Agriculture, Department of Animal Husbandry, Dairying and Fisheries, Krishi Bhawan, New Delhi

Bhawana RK., Basniwal HS, Buttar VK, Jain N (2011) Curcumin nanoparticles: preparation, characterization and antimicrobial study. J Agric Food Chem 59 (5): 2056-2061

Chan BC, Hon KL, Leung PC, Sam SW, Fung KP, Lee MY (2008) Traditional Chinese medicine for atopic eczema: Penta herbs formula suppresses inflammatory mediators release from mast cells. J Ethnopharmacol 120:85 91

Department of Animal Husbandry, Dairying \& Fisheries (2017) Annual Report

Fleiss P (1988) Herbal remedies for the breastfeeding mother. Mothering Summer 68-71

Hashemi SR, Davoodi H (2011) Herbal plants and their derivatives as growth and health promoters in animal nutrition. Veterinary Research Communication 35:169-80

Javale P, Sabnis S (2010) Antimicrobial properties and phytochemical analysis of Phyllanthus emblica. Asian J Exp Biol Sci 3: 91-95
Khana A, Ahmedb T, Rizwanc M, Khanc N (2018) Comparative therapeutic efficacy of Phyllanthus emblica (Amla) fruit extract and procaine penicillin in the treatment of subclinical mastitis in dairy buffaloes. Microbial Pathogenesis 115: 8-11

Klastrup O, Schmidt MP (1974) Nordiske rekommendationer vedrorende mastitundersogelser af kirtelprover. Nordisk Veteran ar-Medicinsk Tidskrift 26:197-204 (In Norwegian)

Kumar N, Manimaran A, Sivaram M, Kumaresan A, Jeyakumar S, Sreela L, Mooventhan P, Rajendran D (2017) Influence of clinical mastitis and its treatment outcome on reproductive performance in crossbred cows: A retrospective study. Veterinary World 10(5): 485-492

Moretain JP (1986) Les medicaments et la qualite du lait: le problem des residuesd' antibiotiques, RIE Technicien du Laite 6: 10-16

Nandivada LS, Amyes SG B (1990) Plasmid mediated B- lactam resistance in pathogenic Gram- Negative bacteria isolated in south India. J Antimicrob. Chemotherap 26: 279-290

NAAS (2013) Mastitis management in dairy animals. Policy Paper No. 61, National Academy of Agricultural Sciences, New Delhi, p. 1-12

Patel VK, Chauhan HD, Pawar MM, Srivastava AK, Prajapati KB (2017) Effect of herbal galactogogue supplementation on production performance of lactating Kankrej cows. Int J Curr Microbiol App Sci 6 (12): 2093-2098

Sharma N, Mmukherjee R, Ingale SL, Jadhav R (2010) Effect of Phyllanthus embilica on ceruloplasmin in bovine Staphylococcal mastitis. Indian J Vet Res 19: 19-24

Sharma N, Rho GJ, Hong YH, Kang TY, Lee H K, Hur TY, Jeong DK (2012) Bovine mastitis: an Asian perspective. Asian J Anim Vet Adv 7(6): 454-476

Sharma A, Prasad S, Singh Y, Bishisth R (2013) Effect of polyherbal preparation supplementation on immunity and udder health of periparturient Karan-Fries crossbred dairy cows. Journal of Applied Animal Research 42(2): 217-221

Singhal SP (1995) Study on the effect of feeding Payapro on milk yield in lactating cows. Dairy Guide 1: 45-47

Srivastava AK, Kumaresan A, Manimaran A, Kumar S (2015) Mastitis in dairy animals: An update. Satish Serial Publishing House

Sudhan NA, Sharma N (2010) Mastitis: An important production disease of dairy animals. In: Farm management and diseases. SMVS' Dairy Year Book. pp. 72-88

Sunder J, De AK, Jeyakumar S, Kundu A (2013) Effect of feeding of Morinda citrifolia fruit juice on the biophysical parameters of healthy as well as mastitis-affected cow milk. J Appl Anim Res 41:29-33

Thakur SS, Tyagi AK, Singhal KK (2006) Effect of a commercial herbal feed supplement on the performance of lactating cows. Indian Journal of Animal Nutrition 23: 244-246 